Diabetologia 8, 283-286 (1972)

(C) by Springer-Verlag 1972

\title{
A Method for Measuring the Release of Gut Glucagon-Like Immunoreactivity from Rat Jejunum ,In Vitro“"
}

\author{
R. Zandomeneghi and K.D. Buchanan \\ Department of Medicine, The Queen's University of Belfast, N. Treland \\ Received: November 9, 1971, accepted: February 22, 1972
}

Summary. A convenient method for measuring the release of gut glucagon-like immunoreactivity (GLI) from rat jejunal pieces incubated 'in vitro' is described. The method utilises Trasylol, EDTA, and excessive glucagon antibody to prevent GLI breakdown. There was satisfactory recovery of added pancreatic glucagon to the incu bates, and a highly significant release of GLI was recorded when high glucose concentrations $(5-40 \mathrm{~g} \%)$ were incubated with the pieces.

Méthode de mesure de la libération de la substance intestinale douée de l'immunoréactivité du glucagon (glucagonlike) à partir du jéjunum de rat "in vitro"

Résumé. Les auteurs décrivent une méthode conmode pour mesurer la libération de la substance intestinale immunologiquement glucagon-like (GLI) à partir de fragments de jéjunum de rat, incubés "in vitro". La méthode utilise du trasylo], de l'EDTA et un excès d'anticorps anti-glucagon pour empêcher la dégradation du GLI. Il y avait une récupération satisfaisante du glucagon pancréatique ajouté aux incubats, et une libération de
GLI hautement significative a été enregistrée lorsque de fortes de concentrations de glucose $(5-40 \mathrm{~g} \%)$ étaient mises à incuber avec les fragments.

Methode zur Bestimmung der Freisetzung von glucagonähnlicher immunologischer Alstivität des Darmes aus dem Jejunum der Ratte "in vitro".

Zusammenfassung. Es wird eine brauchbare Methode zur Bestimmung der Freisetzung von glucagonähnlicher immunologischer Aktivität (GLI) des Darmes beschrieben. Die Methode benutzt Trasylol, EDTA und einen Überschuß von Glucagonantikörpern, um den Abbau von GLI zu verhindern. Die Rückgewinnung von zugefügtem Pankreasglucagon aus den Inkubaten war zufriedenstellend und eine hoch signifikante Freisetzung von GLI wurde beobachtet, wenn hohe Glucosekonzentrationen $(5-40 \%)$ mit den Darmstücken inkubiert wurden.

Key words: Glucagon-like immunoreactivity; jejunal pieces; in vitro; antibody; immunoassay; glucose.

\section{Introduction}

Samols et al. (1965) found that the administration of oral glucose resulted in increased levels of immunoreactive glucagon in the circulation and further studies suggested that this was of intestinal rather than pancreatic origin (Samols et al., 1966). Unger et al. (1966) have confirmed the presence of immunoreactive glucagon in the intestine and in a survey have found large amounts to be present in the jejunum, ileum and colon, with smaller amounts in the stomach and duodenum. This gut material differs from pancreatic glucagon in several respects, in that it is of larger molecular weight, is devoid of glycogenolytic activity and can differ in its reactions with antibodies against pancreatic glucagon (Valverde et al., 1970a; Valverde et al., 1970b). For these reasons Unger has coined the descriptive term 'glucagon-like immunoreactivity' (GLI) to avoid confusion with pancreatic glucagon. Gut GLI has not as yet been purified and its biological properties remain largely unknown. Problems of specificity, degradation and sensitivity bedevil attempts to meaningfully interpret circulating blood levels of immunoreactive glucagon. For this reason an in vitro system for the study of gut GLI release would be useful and it is the purpose of this communication to describe a convenient model for studying the release of gut GLI from intestinal pieces which provides rapid and reliable data.

\section{Materials and Methods}

\section{Assay Materials}

Crystalline glucagon (Novo) was labelled with Todine ${ }^{125}$ by a modification of the method of Greenwood et at. (1963), and purified on finely precipitated silica (Quso G 32, Philadelphia Quartz Company). Separation of free from bound hormone was effected by dextran and horse serum (Burroughs Wellcome No. 5) coated charcoal (Norit A) (Buchanan and MeCarroll, 1971). Glucagon antibodies were produced in New Zealand white male rabbits by repeated injections of crystalline glucagon conjugated to erystalline egg albumin (Koch-Light). The animals were bled after the second and subsequent immunisations, and the sera processed for titre, affinity and specificity. The antisera used in these experiments were from a single animal ( $G 57)$ and showed strong crossreaction with gut GLI of porcine and rat origin.

\section{Preparation of Intestinal Pieces}

A flow diagram for the procedure is shown in Fig. 1. Albino Wistar rats $(200-250 \mathrm{~g})$ fed ad libitum were killed by a blow on the head. The intestine was immediately removed, the proximal $15 \mathrm{~cm}$ discarded and the next $50 \mathrm{~cm}$ used in the studies. The intestinal lumen was washed with Krebs Ringer Bicarbonate (KRB) buffer and the intestine was then everted. One-cm pieces were prepared and incubated in $1 \mathrm{ml}$ of KRB buffer supplemented by $1 \%$ human albumin 
(Blood Products Laboratory), 5 mM EDTA, 1000 KIU of Trasylol (FBA Pharmaceuticals), and excessive glucagon antibody. Some tubes were included without antibody to serve as non-specific controls in the subsequent glucagon assay. Materials which possibly affected the release or suppression of gut GLI and pancreatic glucagon standards were prepared in the same buffer. The pieces were incubated in stoppered glass tubes for $25 \mathrm{~min}$ at $37^{\circ} \mathrm{C}$ in a metabolic bath with

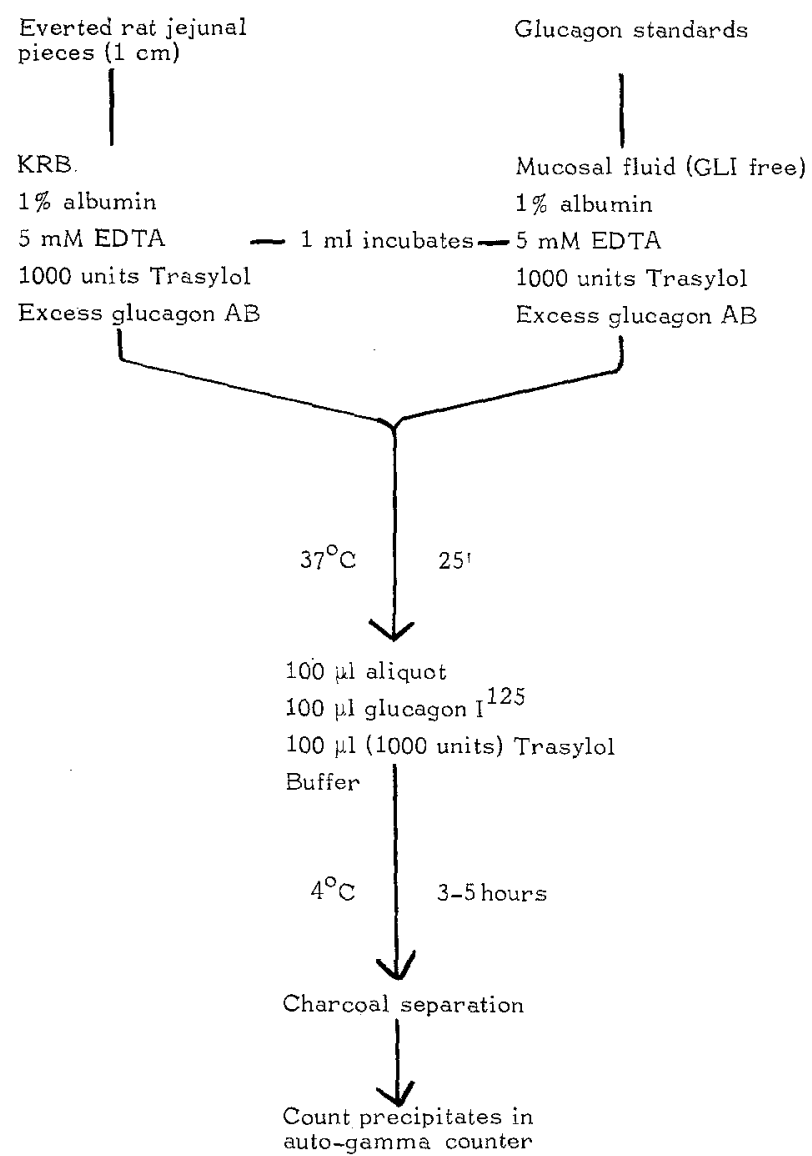

Fig. 1. Flow diagram for incubation of intestinal pieces and the measurement of GLI

100 oscillations per minute. Pancreatic glucagon standards in $100 \mu \mathrm{l}$ amounts were added to glucagon-free mucosal fluid to give final concentrations of $0-25 \mathrm{ng} /$ $\mathrm{ml}$ of glucagon. This 'glucagon-free' mucosal fluid was prepared by incubating rat intestine at $37^{\circ} \mathrm{C}$ for $1 \mathrm{~h}$ in KRB albumin buffer but withont Trasylol, EDTA and antibody, and this resulted in the complete destruction of released glucagon. The glucagon stand. ards in 'glucagon-free' mucosal fluid were incubated identically with intestinal pieces, and also supplemented by Trasylol, EDTA and antibody in similar concentrations as the intestinal pieces. After the $37^{\circ} \mathrm{C}$ incubation the tubes were rapidly removed to an ice bath, allowed to sit for 5 min to allow equilibration and duplicate $100 \mu \mathrm{l}$ aliquots removed for glucagon radio- immunoassay to tubes prepared with $100 \mu$ glucagon $\mathrm{I}^{125}(0.1-0.3 \mathrm{ng})$ and $1000 \mathrm{KIU}$ Trasylol $(100 \mu \mathrm{l})$ and 100 ul 40 mM phosphate buffer pH 7.4 with $2 \%$ horse serum. These tubes were then incubated at $4^{\circ} \mathrm{C}$ between 3 and $4 \mathrm{~h}$ before separation by charcoal. The charcoal precipitates were counted in a Panax autogamma counter, 15000 to 20000 counts being recorded in each sample. The percentage of counts bound to antibody was calculated and a plot of bound counts against glucagon concentration constructed for the glucagon standards. Gut GLI amounts were calculated from the standard curve and expressed as $\mathrm{ng} / \mathrm{ml}$ pancreatic glucagon equivalents.

\section{Results}

\section{The Glucagon Assay}

A glucagon standard curve is shown in Fig. 2. As incubations were performed in the presence of excess antibody in relationship to glucagon, maximum sen-

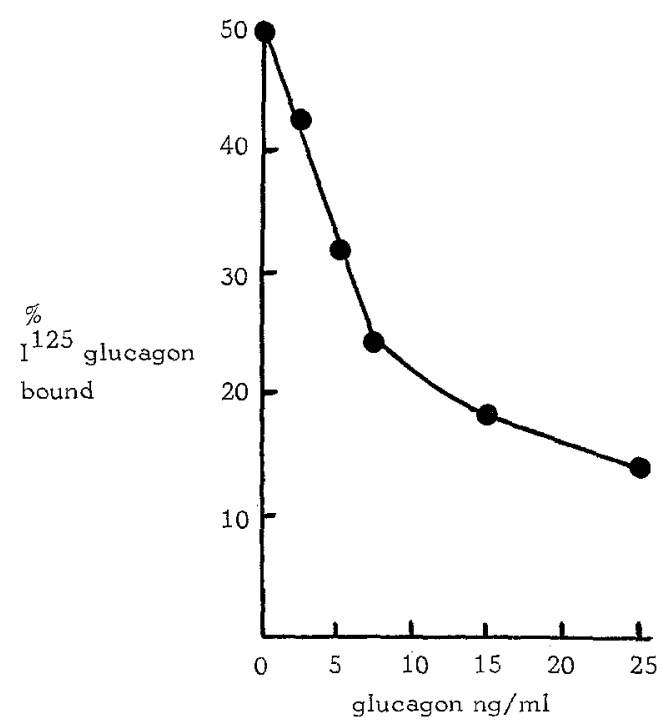

Fig. 2. A standard curve for glucagon. Incubation was performed at $4^{\circ} \mathrm{C}$ for $3 \mathrm{~h}$

sitivity was achieved by shortening the optimum reaction time, $(24 \mathrm{~h})$ in the second incubation to $3-5 \mathrm{~h}$. This resulted in between 35 and $45 \%$ binding of labelled glucagon in the alosence of unlabelled glucagon. This made possible the determination of $1 \mathrm{ng} / \mathrm{ml}$ of glucagon. Similar results were obtained in 'glucagonfree' mucosal fluid and KRB albumin buffer but incubation in mucosal fluid was preferred as it most closely resembled the conditions of the incubated intestinal pieces.

\section{Recovery Studies}

Because of the presence of multiple proteases in the intestinal mucosal cells which rapidly destroy glucagon, methods had to be devised to prevent glucagon de- 
gradation. Trasylol, a known proteolytic inhibitor, and EDTA were found to be insufficient in themselves to give adequate recovery of added glucagon to the incubation medium. Therefore the method of Malaisse et al. (1967) which uses excessive insulin antibody to protect insulin from degradation in pancreatic incubates was modified for the present studies. Pancreatic glucagon in $100 \mu \mathrm{l}$ amounts, calculated to give final concentrations of 10 and $14 \mu \mathrm{g} / \mathrm{ml}$ of glucagon, were added to incubation tubes containing KRB, EDTA, glucagon antibody and intestinal pieces. Incubation was continued for $25 \mathrm{~min}$, along with tubes containing pieces but no added glucagon (basal tubes), and the standard curve tubes. The recovery of pancreatic glucagon added to the incubation tubes containing the intestinal pieces was calculated by subtracting the basal concentrations of released gut GLI from the concentrations when glucagon was added. The recoveries were for $10 \mathrm{ng} / \mathrm{ml} 92.5 \% \pm 5.9(n=16)$ and for $14 \mathrm{ng} / \mathrm{ml} 91.4 \%+2.5(n=9)($ mean \pm SEM). The basal release was $2.74 \mathrm{ng} / \mathrm{ml} \pm 0.14(n=49)$. Prolonging the incubation beyond $25 \mathrm{~min}$ resulted in poorer glucagon recoveries.

\section{Glucose Concentration}

Different concentrations of glucose were incubated with intestinal fluid to test their effect on gut GLI release and the results are shown in Fig. 3. Highly significant increases in gut GLI were achieved using concentrations of glucose between 5 and $40 \mathrm{~g} \%$.

GLI RELEASE FROM RAT JEJUNAL PIECES

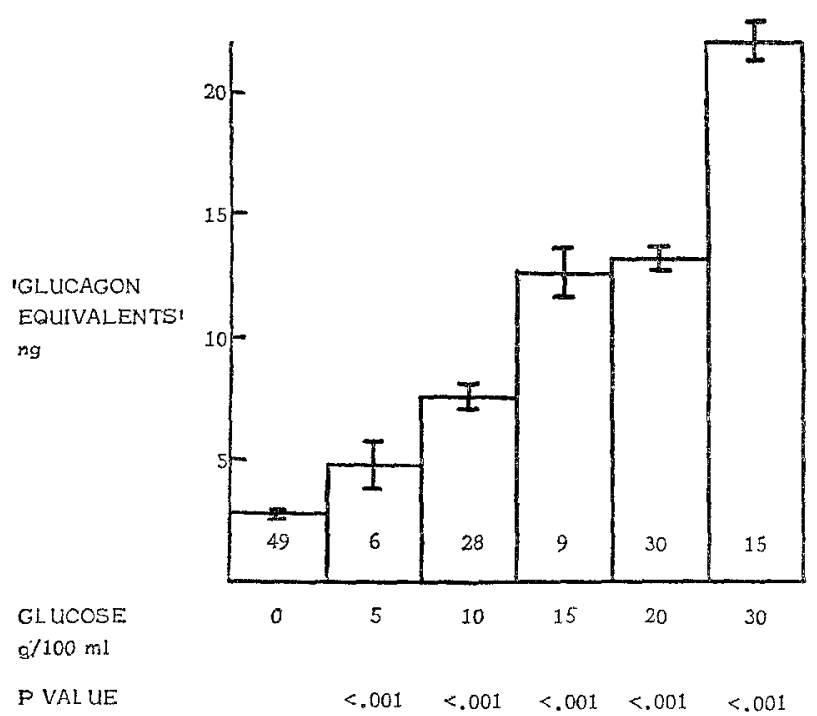

Fig. 3. The effect of increasing glucose concentrations on gut GLT release. Results are expressed as the mean ! SEM and the numbers in each group are shown within the bars. Levels of significance by student's $t$ test are calculated in comparison with basal GLI release when glucose was absent
In a further series of experiments the effect of lower concentrations of glucose was tried on gut GLI release. AT $1 \mathrm{~g} \%$ glucose there was a highly significant gut GLI release $(p<0.001)$ when compared with tubes without glucose (0 glucose $0.99 \pm 0.19 \mathrm{ng} / \mathrm{ml} ; 1 \mathrm{~g} \%$ glucose $3.46 \pm 0.31 \mathrm{ng} / \mathrm{ml}$ ) (mean \pm SEM). Although Mannitol at 20 and $40 \mathrm{~g} / 100 \mathrm{ml}$ produced a significant increase in gut GLI release, $3.84 \pm 0.16 \mathrm{ng} / \mathrm{ml}(p<$ $0.01)$ and $3.63 \pm 0.28 \mathrm{ng}(p<0.025) / \mathrm{ml}$ respectively, compared with $2.74 \pm 0.14 \mathrm{ng} / \mathrm{ml}$ basal release, this was trivial compared with the glucose effects. The significant gut GLI response to $1 \mathrm{~g} / 100 \mathrm{ml}$ glucose would suggest that the GLI release may have physiological meaning. A simple osmotic effect appears unlikely from the Mannitol experiments. One $\mathrm{g} / 100 \mathrm{ml}$ glucose produced an absolute rise of $2.47 \mathrm{ng} / \mathrm{ml}$ GLI (250\% basal) compared with only $0.89 \mathrm{ng} / \mathrm{ml}(132 \%)$ with $40 \mathrm{~g} / 100 \mathrm{ml}$ Mannitol.

\section{Discussion}

Luckyx and Lefebvre (1968) described an in vitro technique for measuring the release of gut GLI. How ever they took no steps to prevent glucagon breakdown and do not report recovery studies. In our experience even incubation systems where the mucosal and serosal surface of the gut are bathed separately as in the everted intestinal sac (Wilson and Wiseman, 1954) result in rapid glucagon breakdown, suggesting that mucosal enzymes gain entry into the serosal fluid. The system of Luyckx and Lefebvre also suffers from lack of sensitivity caused mainly by the fact that gut GLI is released into a large incubation fluid volume of $5 \mathrm{ml}$. The technique described in the present paper shows that by the use of Trasylol, EDTA and escessive antibody, glucagon breakdown can be prevented and satisfactory recoveries of added glucagon obtained. The glucagon is released into a $1 \mathrm{ml}$ volume, allowing maximum sensitivity. Gassing of the incubating flasks was not found to be necessary.

The stimulation of gut GLI release by glucose is in agreement with the in vivo findings of the effect of oral glucose (Samols et al., 1965), and suggests that the incubated intestinal pieces function satisfactorily. The technique is convenient and rapid and simple to perform, and appears to be an excellent model for studying the physiology and role of intestinal GLI. Such a model is of considerable importance because of the difficulties of interpretation of present glucagon radioimmunoassay methods in peripheral circulating blood. The method is currently being used in this laboratory to study factors which might influence gut GLI release.

Acknowledgments. Dr. Zandomeneghi is in receipt of a CNR-NATO scholarship and this work was supported by grants from the British Diabetic Association and the British Medical Research Council. FBA Pharmaceuticals generously supplied Trasylol and Novo Laboratories donated glucagon. 
Buchanan, K.D., MeCarroll, A.M.: Radio-immunoassay mothods, p. 266. Edinburgh and London: Churchill Livingstone 1971.

Greenwood, F.C., Hunter, W.M., Glover, J. S.: The preparation of ${ }^{131}$ I-labelled human growth hormone of high specific radioactivity. Biochem. J. 89, 114-123 (1963).

Luyckx, A.S., Lefebvre, P.J.: Protein and polypeptide hormones, p. 884. International Congress Series No. 161. Amsterdam: Excerpta Medica Foundation 1968.

Malaisse, W., Malaisse-Lagae, F.: A new method for the measurement in vitro of pancreatic insulin secretion. Endocrinology 80, 99-108 (1967).

Samols, E., Tyler, J., Magyesi, C., Marks, V.: Immunochomical glucagon in human pancreas, gut and plasma. Lancet 1966 II, 727-729.

- - Marri, G., Marks, V.: Stimulation of glucagon secretion by oral glucose. Lancet $\mathbf{1 9 6 5}$ II, 1257-1259.
Unger, R.H., Ketterer, M., Eisentraut, A.M.: Distribution of immunoassayable glucagon in gastrointestinal tissues. Metabolism 15, 865-867 (1966).

Valverde, I., Rigopoulou, D., Marco, J., Faloona, G.R., Unger, R.H.: Characterisation of glucagon-like immunoreactivity (GLI). Diabetes 19, 614-623 (1970a).

- _ _ - - Nolecular size of extractable glucagon and glucagon-like immunoreactivity (GLI) in plasma. Diabetes $19,624-629(1970 \mathrm{~b})$.

Wilson, T.H., Wiseman, G.: The use of sacs of everted small intestine for the study of the transference of substances from the mucosal to the serosal surface. J. Physiol. 123, 116-125 (1954).

Dr. R. Zandomeneghi

Tstituta di Clinica IVedica Policlinico

I-4100 Modena, Italy 